\title{
Trophodynamics of the Fish Valenciennellus tripunctulatus. III. Energetics, Resources and Feeding Strategy
}

\author{
Ronald C. Baird and Thomas L. Hopkins \\ Department of Marine Science, University of South Florida, 830 First Street South, St. Petersburg, Florida 33701, USA
}

\begin{abstract}
A model was constructed which relates energy in diet to metabolic requirements for the mesopelagic zooplanktivore fish Valenciennellus tripunctulatus. Linear and Von Bertalanffy growth models were used to explore the energetic consequences of a number of feasible age/growth strategies. Maximum efficiencies were obtained with linear growth to about $30 \mathrm{~mm}$ in $1 \mathrm{y}$. Efficiencies declined rapidly for slower growth strategies. It was hypothesized that an 'annual' life history strategy was optimum based on energetic considerations. Copepod prey in the 1-2 $\mathrm{mm}$ size class were an order of magnitude more abundant and over 4 times higher in caloric content than larger size classes. $V$. tripunctulatus, however, is highly efficient in obtaining calories from larger prey size classes (2-4 mm) which contain a high caloric content per individual. The resource field places severe constraints on predator growth and at $38 \mathrm{~mm}$ no surplus energy is estimated available from daily ration over and above metabolic requirements. $V$. tripunctulatus should be sensitive to 'nearfield' competitors as well as 'remote' predators grazing zooplankton populations in different space/time.
\end{abstract}

\section{INTRODUCTION}

Ecologists have recently begun to explore organismenvironment interactions in terms of genetic systems (populations sensu Mayr, 1963) which delineate adaptive strategies' that allow these systems to persist. These strategies are envisioned as being adaptively directed or 'optimized' through natural selection (e.g. Levins, 1968; Morse, 1971; Baird, 1974). The strategic concept has been applied to feeding and a sizable literature on models of feeding strategies now exists (e.g. MacArthur and Pianka, 1966; Emlen, 1966, 1968; Slobodkin, 1968; Holling, 1968; Schoener, 1971). In this paper we consider the role of energetics in the trophodynamics of the small mesopelagic fish Valenciennellus tripunctulatus and explore the energetic consequences of patterns of resource availability in relation to the more general concepts of life history and feeding strategies in mesopelagic zooplanktivores.

\section{ENERGY BUDGETS}

We have attempted to construct an energy budget for Valenciennellus tripunctulatus based on known prop- erties of the fish and its diet. Direct metabolic measurements on deep sea fishes are rare (Torres et al., 1979) and only two parameters in the equation that follows were directly measured. While the metabolic cost functions used in the model are consistent with our present understanding of the processes involved and serve as first approximations only, they are necessarily based on extrapolations from existing data in the literature. Nonetheless the energy budget model allows us to develop biologically reasonable scenarios about critical ecological processes that are not well known and about which information is exceedingly difficult to obtain.

An equation developed by investigators of fish trophodynamics was used to express the dynamics of energetics and metabolism (e.g. Warren and Davis, 1967; Weatherly, 1972). The equation, expressed in terms of calories, states that:

$$
\begin{gathered}
Q_{c}=Q_{g}+Q_{w}+Q_{d}+Q_{s}+Q_{a} \\
\text { or } \\
Q_{c}=Q_{g}+Q_{s}+Q_{r}
\end{gathered}
$$

where: $\quad Q_{c}=$ energy of ingested ration

$$
Q_{\mathrm{g}}=\text { increase in potential energy }
$$
through growth 


$$
\begin{aligned}
& \mathrm{Q}_{\mathrm{w}}=\text { energy lost as feces, urine and }
\end{aligned}
$$

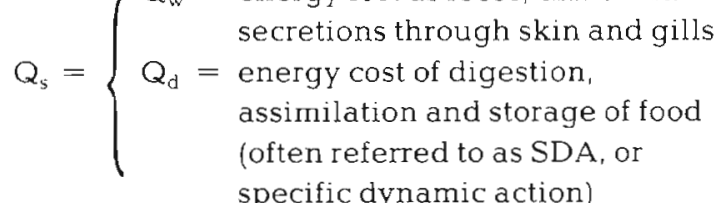

$$
\begin{aligned}
& Q_{r}=\left\{\begin{aligned}
Q_{s}= & \text { energy of metabolism of unfed } \\
& \text { resting fish, i.e. standard or } \\
& \text { basal metabolism } \\
Q_{\mathrm{a}}= & \text { energy of activity in excess of } \\
\text { standard metabolism, e.g. } & \text { swimming }
\end{aligned}\right.
\end{aligned}
$$

Assumptions and approximations for each term of the equation were as follows:

$Q_{c}$ : Estimated from approximations of total food ingested over a given time period multiplied by its caloric value. Since copepods constituted $95 \%$ or more of the diet of Valenciennellus tripunctulatus over all sizes of fish examined, the caloric content of the ingested ration was based on a copepod diet. As determined by Comita and Schindler (1963) for the genus Calanus, $5914 \mathrm{cal} \mathrm{g}^{-1}$ ash-free dry weight (AFDW), adjusted for $5 \%$ salt error in our prey weights (i.e. $5914 \times 0.95=5617 \mathrm{cal} \mathrm{g}^{-1}$ ), was used for caloric conversion of prey biomass.

$Q_{g}$ : Increase in potential energy through growth of an individual $\left(5617 \mathrm{cal} \mathrm{g}^{-1} \mathrm{DW}\right)$. Weights were based on direct measurements of the length/dry weight relationship in Valenciennellus tripunctulatus (Hopkins and Baird, 1981).

$Q_{w}$ : A figure of $0.22 Q_{c}$ was used to account for losses to urine and feces, a conservative estimate based on a wide spectrum of teleost fishes (Brett and Groves,
1979). Losses from leakage and skin secretions were assumed to be minimal.

$Q_{d}$ : Estimates of specific dynamic action or "entropic tax are as high as $0.46 Q_{d}$ (Warren and Davis, 1967) and considerable variation has been reported in teleosts (Brett and Groves, 1979). Recent estimates on the bleak are about 0.15 Q (Muir and Niimi, 1972; Ware, 1975), and we have chosen the latter as representing the most efficient estimate reported in the literature.

$Q_{\mathrm{s}}+Q_{\mathrm{a}}$ : Neither standard metabolism or active metabolism have been precisely determined for midwater fishes. Based on estimates of 'routine' or 'normal' activity (sensu Childress, 1975), a value of approximately $0.115 \mu \mathrm{l} \mathrm{O} \mathrm{Og}^{-1}$ wet wt $\mathrm{h}^{-1}$ was calculated for the mesopelagic hatchetfish Argyropelecus sladeni by Childress and Nygaard (1973), and that value was used here for respiration. A. sladeni exhibits limited vertical migration in the upper mesopelagic environment (minimum depth of occurrence: $100 \mathrm{~m}$; see Baird, 1971; Childress and Nygaard, 1973), and is thought to be phylogenetically the least remote from Valenciennellus tripunctulatus of the fish they examined. Respiration was assumed constant per unit weight over all sizes considered. Weight specific respiration rates are known to vary in fishes (e.g. Paloheimo and Dickie, 1966; Weatherley, 1972) with higher rates per unit weight often observed in smaller individuals. The size classes considered here are quite small in range (15-30 $\mathrm{mm})$, however, and per unit weight differences in respiration rate were assumed not to greatly effect our first order approximations (i. e. other sources of variability are likely to exceed any size effect). For $V$. tripunctulatus, AFDW is $0.87 \mathrm{DW}$, and, using Childress

Table 1. Valenciennellus tripunctatus. Regressions on fish standard length ( $\left.\mathrm{X}_{;} \mathrm{mm}\right)$ of various diet characteristics (Y). Regressions 1 and 2 were non-significant (N. S.); 5 was significant only to $F=0.05$; all other regressions were significant to at least $F<0.01$. Stomach and diet data are from fishes taken during period of most active feeding. Y values require the conversion indicated in the transformation column.

\begin{tabular}{|c|c|c|c|c|c|c|}
\hline Dependent variable & $\begin{array}{l}\text { Regression } \\
\text { equation }\end{array}$ & $\begin{array}{l}\text { Transfor- } \\
\text { mation }\end{array}$ & $\begin{array}{l}\text { Corr. } \\
\text { Coef. }\end{array}$ & $\begin{array}{l}\text { Range } \\
\text { of } \\
Y\end{array}$ & $\begin{array}{l}\text { No. fish } \\
\text { in } \\
\text { sample }\end{array}$ & Comments \\
\hline $\begin{array}{l}\text { 1. Avg. no. prey items per } \\
\text { stomach }\end{array}$ & N.S. & $(Y+0.5)^{1 / 2}$ & 0.08 & $0-24$ & 195 & $\begin{array}{l}\text { Empty stomachs included } \\
\text { in average }\end{array}$ \\
\hline $\begin{array}{l}\text { 2. Max. no. prey items per } \\
\text { stomach }\end{array}$ & N.S. & none & 0.27 & $9-24$ & 13 & $\begin{array}{l}\text { Based on stomachs with } \\
\text { most prey in each fish } \\
\text { size class }\end{array}$ \\
\hline 3. Fish biomass (mg AFDW) & $Y=-0.116+0.061 X$ & $\log _{10} Y$ & 0.95 & $6.1-31.8$ & 6 & \\
\hline $\begin{array}{l}\text { 4. Avg. prey biomass in } \\
\text { stomachs (mg DW) }\end{array}$ & $Y=0.637+0.013 X$ & $(Y+0.5)^{1 / 2}$ & 0.22 & $0.0-1.87$ & 195 & $\begin{array}{l}\text { See comment for } \\
\text { Equation } 1\end{array}$ \\
\hline $\begin{array}{l}\text { 5. Max prey biomass in } \\
\text { stomachs (mg DW) }\end{array}$ & $Y=-1.379+0.103 X$ & none & 0.86 & $0.57-1.87$ & 13 & $\begin{array}{l}\text { Based on stomachs with } \\
\text { most biomass in each fish } \\
\text { size class }\end{array}$ \\
\hline
\end{tabular}


and Nygaard's (1973) wet weight (WW) to DW ratios, our AFDW regression (Table 1), and integrating over the desired time interval (e.g. days, years), total respiration is obtained. This total actually represents mean respiration over a given time interval (i.e. it averages respiration rates which vary over shorter time intervals such as a diel period). To convert respiration to energy cost or calories, values of 5007, 4686, and $4500 \mathrm{cal} \mathrm{l}^{-1}$ $\mathrm{O}_{2}$ were assumed for the combustion of carbohydrate, lipid, and protein (Giese, 1962). The ratio of these components in the copepod genus Calanus is reported to be 1.0:5.4:33.6 (Raymont, 1963). By the assumption of those proportions and their oxy-caloric equivalency, a representative value for copepods was estimated to be $4538 \mathrm{cal} \mathrm{l}^{-1} \mathrm{O}_{2}$.

We have used the distributional information, diet composition data, and minimum/maximum estimates of daily ration developed in Hopkins and Baird (1981) as input to the energetic and growth models used here. Regression Equations 1-5 were used to determine fish weight (AFDW), prey numbers, and biomass of food consumed in the daily ration for any given fish length. The daily ration-fish length regression can then be integrated over the various time periods and growth rates being considered, to calculate total food consumed during that period. For example, if growth is linear, the total prey biomass ingested during growth from 10 to $30 \mathrm{~mm}$ during a time period of 11 months is estimated at 133 and $255 \mathrm{mg}$ DW, respectively, for average and maximum ration. This is the method used to calculate caloric intake for the various periods and growth rates considered in Table 2.

No direct means were available for the determination of actual age/growth relationships, and such data are non-existent for mesopelagic species in low latitude oligotrophic environments. Several feasible growth strategies were examined in relation to ingested energy. An arbitrarily determined period of $30 \mathrm{~d}$ was allowed for larval development and commencement of metamorphosis at approximately $10 \mathrm{~mm}$ SL. This was based on developmental times for certain clupeid species having pelagic larvae (e.g. Houde and Palko, 1970; Houde and Swanson, 1975). Energy consumed during the pre-metamorphic period was not considered in the analysis.

The maximum length of an individual observed in our collections was $35 \mathrm{~mm} \mathrm{SL}$, with the great majority of the population ranging from 15-30 mm SL (Hopkins and Baird, 1981; their Fig 3). Similar size ranges have been reported for other North Atlantic populations (Krueger, 1972; Badcock and Merrett, 1976). Energy budgets were calculated for a maximum fish length of 38 or $40 \mathrm{~mm}$ SL depending on the growth model used.

Two basic models were used to calculate potential rates of growth for various time periods. One is a linear model in which,

$$
l t=1 t_{0}+t / t_{m}\left(1 t_{m}-l t_{0}\right)
$$

where: $l t=$ length at time $t_{;} l t_{0}=$ length at $t_{0}$ (i.e. $10 \mathrm{~mm} \mathrm{SL}) ; \mathrm{lt}_{\mathrm{m}}=$ length at maximum assumed age $\mathrm{t}_{\mathrm{m}}$; $t_{0}=0.08$ y (approximately $30 \mathrm{~d}$ ); time of larval development; $t_{m}=$ assumed maximum age. The other is a curvilinear or Von Bertalanffy (1938) model, which expresses growth rate as decreasing with increasing size. In this model, lt is expressed as follows:

$$
\text { lt }=1 \infty\left(1-\mathrm{e}^{-\mathrm{R}\left(\mathrm{t}-\mathrm{l}_{0}\right)}\right)
$$

where: $1 \infty=a$ theoretical maximum length (i.e. arbitrarily set at $38 \mathrm{~mm} \mathrm{SL);} \mathrm{R}=$ growth term or the rate at which growth curve reaches the asymptotic length.

Energy budgets were then calculated based on maximum and minimum daily ration for various assumed rates of linear growth (Table 2). Various time periods $\left(t_{m}\right)$ from 5 to 23 months corresponding to maximum ages of 0.5 to $2 y$, were used to determine linear rates of

Table 2. Valenciennellus tripunctulatus. Caloric budget assuming various size ranges, rations and periods of growth. Linear

\begin{tabular}{|c|c|c|c|c|c|c|c|c|c|}
\hline \multirow{2}{*}{$\begin{array}{l}\text { Daily } \\
\text { ration }\end{array}$} & \multirow{2}{*}{$\begin{array}{l}\text { Maximum } \\
\text { length } \\
\text { (1 max, mm) }\end{array}$} & \multirow{2}{*}{$\begin{array}{l}\text { Time } \\
\text { at } 1 \text { max } \\
(y)\end{array}$} & \multicolumn{4}{|c|}{ Energy budget (calories) } & \multicolumn{2}{|c|}{ Balance } & \multirow{2}{*}{$\begin{array}{l}\text { Conversion } \\
\text { efficiency } \\
Q_{g} / Q_{c}(\%)\end{array}$} \\
\hline & & & $Q_{c}$ & $Q_{g}$ & $Q_{s}$ & $Q_{r}$ & cal. & $\% \mathrm{Q}_{\mathrm{c}}$ & \\
\hline \multirow[t]{4}{*}{ Maximum } & 30 & 0.5 & 652 & 245 & 261 & 184 & -38 & $(-) 6$ & $(-) 38$ \\
\hline & 30 & 1.0 & 1435 & 245 & 575 & 405 & 210 & 15 & 17 \\
\hline & 30 & 1.5 & 2220 & 245 & 888 & 625 & 462 & 21 & 11 \\
\hline & 30 & 2.0 & 3006 & 245 & 1202 & 847 & 712 & 24 & 8 \\
\hline \multirow[t]{4}{*}{ Minimum } & 30 & 0.5 & 341 & 245 & 136 & 184 & -224 & $(-) 66$ & $(-172$ \\
\hline & 30 & 1.0 & 750 & 245 & 300 & 405 & -200 & $(-) 27$ & $(-) 33$ \\
\hline & 30 & 1.5 & 1161 & 245 & 464 & 625 & -173 & $(-) 15$ & $(-) 21$ \\
\hline & 30 & 2.0 & 1571 & 245 & 629 & 847 & -150 & $(-) 10$ & $(-) 16$ \\
\hline \multirow[t]{2}{*}{ Maximum } & 35 & 1.0 & 1868 & 510 & 747 & 664 & -53 & (-) 3 & $(-) 27$ \\
\hline & 35 & 1.5 & 2891 & 510 & 1156 & 1036 & 189 & 6 & 18 \\
\hline Minimum & 35 & 2.0 & 1889 & 510 & 755 & 1391 & -767 & $(-) 41$ & $(-) 27$ \\
\hline Maximum & 40 & 2.0 & 4894 & 1046 & 1958 & 2428 & -538 & $(-) 11$ & $(-) 21$ \\
\hline
\end{tabular}
growth assumed 
growth to maximum sizes ( $1 \mathrm{t}_{\mathrm{m}}$ ) of 30,35 , and $40 \mathrm{~mm}$. The Von Bertalanfy model was used to assess the energetic consequences of a longer life cycle in which the growth rate is reduced as age increases. The actual values used in the Von Bertalanffy model produced a rate of growth which is less than that reported for several mesopelagic myctophid species (Odate, 1966; Halliday, 1970; Smoker and Pearcy, 1970) and represents very slow growth compared to known rates in a number of epipelagic marine species. The assumed Von Bertalanffy values were $\mathrm{R}=0.83, \mathrm{t}_{0}=0.08 \mathrm{y}$ and $1 \infty=38 \mathrm{~mm}$, which result in estimates of a mean length of about $20 \mathrm{~mm}$ for age class one, $30 \mathrm{~mm}$ for age two, and $35 \mathrm{~mm}$ for age class three fish.

Graphs of the various modeled growth strategies are depicted in Figure 1. The energy budgets and conversion efficiencies calculated from these growth curves appear in Tables 2 and 3 . Considering first the ration estimate, the caloric equivalents for most crustaceans

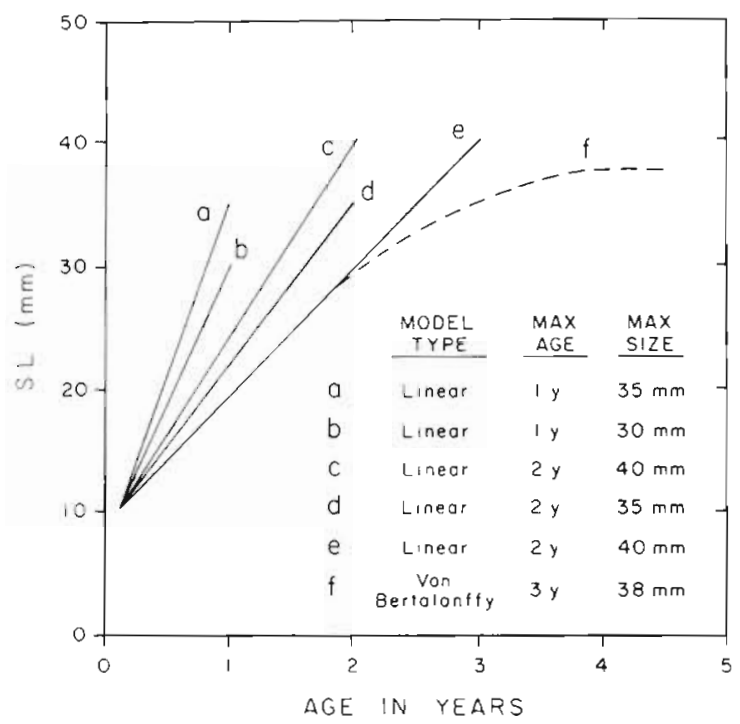

Fig. 1. Valenciennellus tripunctulatus. Projected growth curves based on maximum estimated daily ration (see text)

Table 3. Valenciennellus tripunctulatus. Conversion efficiency in percent of caloric intake at maximum ration to caloric equivalent of fish weight for various lengths and growth rates. Linear growth rates are assumed for Years 1 and 2 ; decline in growth rate (Von Bertalanffy effect) assumed for third year (see Fig. 1). In parentheses: efficiency at balance $\left(\% Q_{g}=0\right)$ obtained by subtracting our excess in energy balance equation (i.e. $Q_{c}$ considered $=Q_{c}$ - surplus)

\begin{tabular}{|c|c|c|c|}
\hline $\begin{array}{l}\text { Maximum } \\
\text { length }\end{array}$ & Year 1 & Year 2 & Year 3 \\
\hline & & & $\begin{array}{c}\text { (Von Bertalanffy } \\
\text { growth) }\end{array}$ \\
\hline 30 & $17(23)$ & $8(12)$ & $<5$ \\
\hline 35 & $27(30)$ & $13(17)$ & 6 \\
\hline
\end{tabular}

fall within narrow limits (5200-5900 $\mathrm{cal} \mathrm{g}^{-1}$ AFDW; Cummins and Wuycheck, 1971), and a major error in caloric conversion is unlikely. The minimum ration as calculated here is considered an underestimate. That is given some support by the data in Table 2 (e.g. growth to $30 \mathrm{~mm}$ appears possible only after 18 mo to $2 \mathrm{y}$ ). The population is apparently not feeding in synchrony and in any given daylight sample empty stomachs may occur, lowering the value for minimum ration. The actual energy intake is predicted to fall between average and maximum as calculated here.

Considering the right side of the energy equation, it is apparent that growth $\left(Q_{g}\right)$ and respiration $\left(Q_{s}+Q_{a}\right)$ are the major factors contributing to energy costs. The other items are a function of ration intake and were conservatively estimated by assuming low values reported in the literature for teleost fishes. $Q_{g}$ is a function of biomass, determinations of which are relatively accurate. Gonad weight was estimated to be $8-10 \%$ of body weight in mature individuals and was included in biomass estimates. Gonadal material, however, is generally higher in energy content than somatic tissue, and an underestimation of caloric conversion at larger fish sizes may result.

Respiratory metabolism $\left(Q_{s}+Q_{a}\right)$ was the most difficuit term to estimate as little metabolic or behavioral data exist. Consequently, a higher uncertainty must be associated with respiratory cost factors. Recent measurements of resting metabolism in several mesopelagic myctophids range from 0.059 to 0.09 ( $\mu$ ) $\mathrm{O}_{2} \mathrm{mgWW}^{-1} \mathrm{~h}^{-1}$ ) (Torres et al., 1979) and are comparable to the 0.115 used here. Our estimate represents 'low routine' activity for $24 \mathrm{~h}$ (Childress and Nygaard, 1973; Childress, 1975). Unexpectedly large metabolic demands from feeding, escape or reproductive behavior (including, for example, increases in metabolism from egg production) might result in underestimation, while periods of very low activity would tend to correct in the other direction.

\section{ENERGETICS AND GROWTH}

A number of important ecological consequences folIow directly from a consideration of the energy budgets presented in Table 2. It is, for instance, unlikely that a size of $30 \mathrm{~mm}$ SL could be reached by Valenciennellus tripunctulatus in 6 mo at either maximum or minimum daily ration. Significant positive energy balances are obtained at maximum daily ration and growth to $30 \mathrm{~mm}$ in $1 \mathrm{y}$. If the true daily ration lies between our mean and maximum, then growth to $27-30 \mathrm{~mm}$ in $1 \mathrm{y}$ can be achieved.

The minimun ration yields negative energy budgets under the age-growth models depicted. Only 
strategies involving long age $(2+y)$, slow growth and small adult size can theoretically produce viable populations of Valenciennellus tripunctulatus at ingestion rates approaching the estimated minimum ration. Daily ration determines the upper limit to any viable age-growth strategy which in this case theoretically limits growth to about $27-32 \mathrm{~mm}$ in the first year.

The energetic implications of various growth strategies in terms of conversion efficiencies (i.e. tissue accumulation efficiency sensu Kozlovsky, 1968) which compare caloric intake (at maximum daily ration) to caloric equivalent of fish weight as growth are apparent in Table 3. Calculations were made on the basis of ingested energy and energy required to exactly balance the energy budget. It can be seen that as the time to reach a given size increases, conversion efficiency decreases. At ages beyond $2 y$, efficiencies fail below $10 \%$. Conversely growth to $35 \mathrm{~mm}$ in $1 \mathrm{y}$ represents an high conversion efficiency $(27 \%)$ which may exceed the metabolic capabilities of vertebrate physiology. Maximum conversion efficiencies of about $25 \%$ have been reported for young fishes under experimental conditions (e.g. Brett et al., 1969, for salmonids) and the estimated $17-23 \%$ efficiencies predicted for growth to $30 \mathrm{~mm}$ in $1 \mathrm{y}$ cannot be excluded on physiological grounds. Growth rates of $35 \mathrm{~mm} \mathrm{SL}$ in $2 y$ also yield efficiencies in excess of $13 \%$. Slower growth options $\left(30-35 \mathrm{~mm} 3 \mathrm{y}^{-1}\right)$ of the Von Bertalanffy type yield lower efficiencies (i.e. less than $10 \%$ ), representing levels of utilization which would theoretically put individuals at a competitive disadvantage.

\section{ENERGETICS, FOOD AVAILABILITY, AND RESOURCE UTILIZATION}

A number of fundamental relationships in the trophodynamics of Valenciennellus tripunctulatus can be depicted in general form from a consideration of energy budgets, estimates of the caloric value of various sized prey items, prey density in the environment, and prey utilization by size class. The information is
Table 4. Size, weight and caloric value as a function of size for the copepod genus Pleuromamma. Caloric equivalency $=$ $5600 \mathrm{cal} \mathrm{g}^{-1} \mathrm{DW} ; \mathrm{DW}=$ dry weight

\begin{tabular}{|ccc|}
\hline Size $(\mathrm{mm})$ & mg DW & Calories \\
\hline 1.0 & 0.007 & 0.039 \\
1.5 & 0.025 & 0.140 \\
2.0 & 0.044 & 0.246 \\
2.5 & 0.068 & 0.381 \\
3.0 & 0.110 & 0.618 \\
3.5 & 0.185 & 1.037 \\
4.0 & 0.294 & 1.647 \\
4.5 & 0.457 & 2.559 \\
5.0 & 0.710 & 3.976 \\
\hline
\end{tabular}

summarized in Tables 4-7. Table 4 lists the estimated caloric equivalency of a size-series of copepods of the genus Pleuromamma using a caloric conversion value for the genus Calanus. From those data, it is possible to obtain a first approximation of the caloric content represented in each prey size class in the environment (Table 5). For purposes of estimate, the caloric equivalency of an individual of length one half the size class range (e.g. $1.5 \mathrm{~mm}$ for size class $1-2 \mathrm{~mm}$ ) was assigned to every individual in that size class. Prey density was taken from data presented by Baird and Hopkins (1981). Information on prey utilization and encounter rates were obtained from the same source and estimates of the caloric contribution of each prey size class to the diet and to total prey available in the expected search volume were made. Data on caloric intake and $\%$ daily prey production removed are listed in Table 6. Daily energy budgets for various adult fish sizes based on the maximum daily ration were calculated (Table 7) assuming a zero daily growth rate $\left(Q_{g}\right.$ set at o). No assumptions were made as to utilization of surplus calories over metabolic costs in this case.

The energetic consequences of diel vertical migration of prey in various size classes are readily apparent (Table 5). The reduction in available energy at night is dramatic and appears to affect all prey size classes. If perception distances remain constant (Tables 6 and 7) and grazing efficiency were set at $100 \%$, available energy at night would be insufficient to support an

Table 5. Estimated caloric content of copepod prey per $\mathrm{m}^{3}$ of water at depths of $300-350 \mathrm{~m}$ proportioned by prey size classes. Caloric equivalency based on members of the genus Pleuromamma and a mean prey size of $1 / 2$ the size range of an individual prey size class. D: day; N: night. Prey availability data from Table 1 of Baird and Hopkins (1981)

\begin{tabular}{|ccccccc|}
\hline $\begin{array}{c}\text { Prey size class } \\
(\mathrm{mm})\end{array}$ & $\begin{array}{c}\text { Estimated calories } \\
\text { item }^{-1}\end{array}$ & \multicolumn{2}{c|}{$\begin{array}{c}\text { Individual items } \mathrm{m}^{-3} \\
\mathrm{D}\end{array}$} & $\mathrm{N}$ & \multicolumn{2}{c|}{$\begin{array}{c}\text { Total calories } \mathrm{m}^{-3} \\
\mathrm{~N}\end{array}$} \\
\hline $0.5-0.9$ & 0.006 & 31.92 & 28.73 & 0.19 & 0.17 & $\begin{array}{c}\mathrm{N} / \mathrm{D} \\
(\%)\end{array}$ \\
$1.0-1.9$ & 0.140 & 24.44 & 16.23 & 3.42 & 2.27 & 90 \\
$2.0-2.9$ & 0.381 & 1.99 & 1.17 & 0.76 & 0.45 & 59 \\
$3.0-3.9$ & 1.036 & 0.70 & 0.30 & 0.72 & 0.31 & 43 \\
$4.0-4.9$ & 2.559 & 0.10 & 0.04 & 0.26 & 0.10 & 38 \\
\end{tabular}


Table 6. Valenciennellus tripunctulatus. Estimated caloric intake of copepods at mean and maximum daily ration as a function of prey size class for individual of $26 \mathrm{mmSL}$ ( $<1 \mathrm{~mm}$ category not considered)

\begin{tabular}{|c|c|c|c|c|}
\hline \multirow[t]{2}{*}{ Parameters } & \multicolumn{4}{|c|}{ Prey size class (mm) } \\
\hline & $1.0-1.9$ & $2.0-2.9$ & $3.0-3.9$ & $4.0-4.9$ \\
\hline Minimum no. eaten $d^{-1}$ & 3.51 & 2.52 & 1.80 & 0.63 \\
\hline Maximum no. eaten $d^{-1}$ & 8.00 & 5.74 & 4.10 & 1.43 \\
\hline No.encountered $\mathrm{d}^{-1}$ & 29.08 & 5.17 & 4.01 & 1.18 \\
\hline Minimum caloric intake $\mathrm{d}^{-1}$ & 0.49 & 0.96 & 1.87 & 1.61 \\
\hline Maximum caloric intake $\mathrm{d}^{-1}$ & 1.12 & 2.19 & 4.25 & 3.66 \\
\hline Caloric value of prey encountered (day) & 4.07 & 1.97 & 4.16 & 3.02 \\
\hline Caloric value of prey encountered (night) & 2.68 & 1.16 & 1.83 & 1.15 \\
\hline$\%$ calories encountered in daytime removed at minimum intake & 12 & 49 & 45 & 53 \\
\hline$\%$ calories encountered in daytime removed at maximum intake & 28 & 111 & 102 & 121 \\
\hline No. items to produce caloric equivalent of largest size class & 18.3 & 6.7 & 2.5 & 1.0 \\
\hline
\end{tabular}

individual of $27 \mathrm{~mm} \mathrm{SL}$ at maximum ration. Further, if, because of decreased light intensity, perception distances were reduced at night by about $1 / 2$ those used for calculations in Table 6 , energy intake could be reduced by about $7 / 8$ that of daytime values if energy costs for search remain constant.

Considering resource utilization, Valenciennellus tripunctulatus appears highly efficient in obtaining energy from the $2-5 \mathrm{~mm}$ prey size classes (Table 6 ). Efficiency falls off, however, for smaller $(<1.9 \mathrm{~mm})$ and larger ( $>4 \mathrm{~mm}$ ) prey. It is also apparent that relatively large increases in density of prey less than $1 \mathrm{~mm}$ in length would be needed to support larger predators while modest increases in larger prey size classes could have profound effects on growth rate and maximum attainable size.

As rations increase with fish length, so do metabolic demands (Table 7). However, both the resource field

Table 7. Valenciennellus tripunctulatus. Daily energy budget as a function of adult size at maximum daily ration. Growth arbitrarily set at zero (i.e. no assumptions made as to how the surplus is used metabolicaliyj. Values expressed in calories day $^{-1}$

\begin{tabular}{|rrrrl}
\hline $\begin{array}{c}\text { Fish size } \\
(\mathrm{mmSl})\end{array}$ & $Q_{c}-Q_{\mathrm{w}}-Q_{\mathrm{d}}-\left(\mathrm{Q}_{\mathrm{s}}+\mathrm{Q}_{\mathrm{a}}\right)=$ Surplus \\
\hline 27 & $8.72-1.92-1.31-2.36=3.13$ \\
30 & $12.08-2.66-1.81-3.59=$ & 4.02 \\
35 & $15.38-3.38-2.31-7.27=2.42$ \\
\hline
\end{tabular}

and predator morphological-physiological characteristics interact to limit the extent to which increased energy can be obtained by simply taking larger prey. Under the present assumptions, there exists an optimum in the vicinity of $30 \mathrm{~mm}$ SL in which daily surplus over metabolic requirements reaches a maximum (Table 7). Theoretically, at a size of $37-38 \mathrm{~mm}$ no surplus would accrue, and no increase in size or other metabolic activity would be possible; to exceed these limits, major changes in perception distance, search volume, or utilization patterns of large prey items must occur. Conversion to prey larger than $4 \mathrm{~mm}$, however, is likely to involve severe metabolic penalties in terms of search and pursuit, since energetically rich prey (e.g. euphausiids, amphipods) are relatively uncommon and more mobile than copepod prey.

\section{EFFICIENCY, OPTIMIZATION, AND COMPETITION}

The trophodynamics of Valenciennellus tripunctulatus may relate to the nature and degree of 'optimization' in adaptive repertoires and to competitive interactions in depauperate mesopelagic environments. A number of characteristics indicative of high efficiency and diet optimization are evident. Feeding is restricted to that time of day when potential available energy intake per unit time is highest (Table 6). Feeding efficiencies are maximum over those prey size-classes in which the product of calories per individual copepod and total calories available is highest (i.e., 2-4 mm). Larger fish appear increasingly efficient at grazing larger prey size-classes. Smaller prey (less than $1 \mathrm{~mm}$ ) are very inefficiently grazed by $V$. tripunctulatus and the energetic profit per item cannot be high.

Adaptations in both predator (Baird and Hopkins, 1981) and prey dictate compromises to the degree to which actual diets approach a theoretical optimum based on simple economic considerations. Specialization in Valenciennellus tripunctulatus apparently includes mechanisms for the efficient utilization of the copepod fraction of the available resource field. It should be noted that copepods constitute much smaller percentages of available prey at sizes greater than $4 \mathrm{~mm}$. Not only are large prey items comparatively rare 
but they also represent groups which are taxonomically and adaptively remote from copepods in terms of behavior, life history, and morphological characteristics. Intraspecific competitive interactions should in turn increase with fish size as more rare, larger prey items are required to meet daily energy requirements. The larger the fish, the greater the impact on the resource field by reason of increased pressure on calorically important large prey, a broader spectrum of size classes in the diet and higher absolute energy requirements.

A mechanism to reduce competition among Valenciennellus tripunctulatus size classes would be vertical segregation by size. This has been documented (e.g. Krueger and Bond, 1972; Clarke, 1974), and evidence published by Badcock (1977) suggests that it may be quite marked. Low density and noncontagious distributions among individuals, particularly as size increases, would also effectively reduce competitive grazing

Concerning inter-specific competition, Valenciennellus tripunctulatus should be sensitive to both cooccurring 'nearfield' as well as 'remote' zooplanktivore predators. Most copepod prey populations occupy broad depth ranges (e.g. Roe, 1974) and many migrate vertically. They are impacted by a large number of mesopelagic fish and shrimp predators grazing over various depths and times. Higher trophic levels, in fact, appear co-exploitatively organized wherein many predator species in the mesopelagic zone are competitively 'linked' to a common resource field and considerable diet overlap is observed (Foxton and Roe, 1974 ; Merrett and Roe, 1974; Donaldson, 1975; Walters, 1976; Hopkins and Baird, 1977; Clarke, 1978; Heffernan and Hopkins, in press). The premium on ecological efficiency, however, imposes a high degree of trophic organization in which mechanisms for partitioning resources can be expected, from theoretical considerations at least, to be well developed. Knowledge of the interaction of body size, energetics, and abundance of predator and prey exhibiting various patterns of distribution in space/time, then, is essential to the understanding of the organization of oceanic ecosystems. It should be emphasized that the present model has concentrated on an intermediate predator and its resource field, the zooplankton. Not considered here, because of inadequate information is the effect of higher level predation (Hayward and McGowan, 1979) on the population dynamics of this species.

\section{LITERATURE CITED}

Badcock, J. (1977). Aspects of the development and biology of post-larval Valenciennellus tripunctulatus (Esmark) and Bonapartia pedaliota Goode and Bean (Pisces,
Stomiatoidea) In: Angel, M. (ed.) A voyage of discovery. Pergamon Press, Oxford, pp. 537-552

Badcock, J., Merrett, N. R. (1976). Midwater fishes in the eastern North Atlantic. I. Vertical distribution and associated biology in $30^{\circ} \mathrm{N}, 23^{\circ} \mathrm{W}$, with developmental notes on certain myctophids. Progr Oceanogr 7:3-58

Baird, R. C. (1971). The systematics, distribution, and zoogeography of the marine hatchetfishes (family Sternoptychidae). Bull. Mus. comp. Zool. Harv. 142: 1-128

Baird, R. C. (1974). Aspects of social behavior in Poecilia latipinna (Lesueur). Rev. Biol. Trop. 21: 399-416

Baird, R. C., Hopkins, T L. (1981). Trophodynamics of the fish Valenciennellus tripunctulatus (Esmark). II. Selectivity, grazing rate and resource utilization. Mar. Ecol. Prog. Ser. 4: $11-19$

Bertalanffy, L. V. (1938). A quantitative theory of organic growth (inquiries on growth laws II). Hum. Biol. 10: 181-213

Brett, J. R., Groves, T. D. D. (1979). Physiological energetics. In: Hoar, W. S., Randall, D. J. (eds) Fish physiology, Vol. 8. Academic Press, London, pp. 279-352

Brett, J. R., Shelbourne, J. E., Shoop, C. T. (1969). Growth rate and body composition of fingerling sockeye salmon, Oncorhynchus nerka, in relation to temperature and rations size. J. Fish. Res. Bd Can. 26: 2363-2394

Childress, J. J. (1975). The respiratory rates of midwater crustaceans as a function of depth of occurrence and relation to the oxygen minimum layer off Southern California. Comp. Biochem. Physiol. 50A: 787-799

Childress, J. J., Nygaard, M. H. (1973). The chemical composition of midwater fishes as a function of depth occurrence off Southern California. Deep Sea Res. 20: 1093-1109

Clarke, T. A. (1974). Some aspects of the ecology of stomiatoid fishes in the Pacific Ocean near Hawaii. Fish. Bull. U. S. 72: $337-351$

Clarke, T. A. (1978). Diel feeding patterns of 16 species of mesopelagic fishes from Hawaiian waters. Fish. Bull. U. S. 76: $495-513$

Comita, G. W., Schindler, D. W (1963). Caloric values of microcrustacea. Science, N. Y. 140: 1394-1395

Cummins, K. W., Wuycheck, J. C. (1971). Caloric equivalents for investigations in ecological energetics. Int. Ass. Theoret. Appl. Limnol. Communic. No. 158: 1-158

Donaldson, H. A. (1975). Vertical distribution and feeding of sergestid shrimps (Decapoda: Natantia) collected near Bermuda. Mar. Biol. 31: 37-50

Giese, A. C. (1962). Cell physiology, W. B. Saunders, Philadelphia

Emlen, J. M. (1966). The role of time and energy in food preference. Am. Nat. 100: 611-617

Emlen, J. M. (1968). Optimal choice in animals. Am. Nat. 102: 385-389

Foxton, P., Roe, H. S. J. (1974). Observations on the nocturnal feeding of some mesopelagic decapod crustacea. Mar. Biol. 28: 37-49

Halliday, R. G. (1970). Growth and vertical distribution of the glacier lantern fish, Benthosema glaciale, in the northwestern Atlantic. J. Fish. Res. Bd Can. 27: 105-116

Hayward, T. L., McGowan, J. A. (1979). Pattern and structure in an oceanic zooplankton community. Am. Zool. 19: 1045-1055

Heffernan, J. J., Hopkins, T. L. (in press). Vertical distribution and feeding of Gennadas and Bentheogennema shrimps (Decapoda: Penaeidea) in the eastern Gulf of Mexico. J. Crustac. Biol.

Holling, C. S. (1968). The tactics of a predator. Symp. R. Entomol. Soc. Lond. 4: 47-58 
Hopkins, T. L., Baird, R. C. (1977). Aspects of the feeding ecology of oceanic midwater fishes. In: Andersen, N. R., Zahuranec, B. J. (eds) Proc. Int. Symp. Prediction of sound scattering in the ocean. Plenum Press, New York, pp. $325-360$

Hopkins, T L., Baird, R. C. (1981). Trophodynamics of the fish Valenciennellus tripunctulatus. I. Vertical distribution, diet and feeding chronology. Mar. Ecol. Prog. Ser. 4: 1-10

Houde, E. D., Palko, B. (1970). Laboratory rearing of the clupeid fish Harengula pensacolae from fertilized eggs. Mar. Biol. 5: 354-358

Houde, E. D., Swanson, L. J. (1975). Description of eggs and larvae of yellowfin menhaden, Brevoortia smithi. Fish Bull. U. S. 73: 660-673

Kozlovsky, D. G. (1968). A critical evaluation of the trophic level concept. I. Ecological efficiencies. Ecology 49: 48-60

Krueger, W. H. (1972). Biological studies of the Bermuda Ocean Acre IV. Life history, vertical distribution and sound scattering in the gonostomatid fish ValenciennelIus tripunctulatus (Esmark). Report to U. S. Navy Underwater Systems Center, Contract \# N00140-72-C-0315, Washington, D. C., pp. 1-37

Krueger, W H., Bond, G. W. (1972). Biological studies of the Bermuda Ocean Acre III. Vertical distribution and ecology of the bristle-mouth fishes (family Gonostomatidae). Report to U. S. Navy Underwater Systems Center, Contract N00140-72-C-0315, Washington, D. C., pp. 1-50

Levins, R. (1968). Evolution in changing environments, Princeton University Press, Princeton

MacArthur, R. H., Pianka, E. R. (1966). On optimal use of a patchy environment. Am. Nat. 100: 603-609

Mayr, E. (1963). Animal species and evolution, Harvard University Press, Cambridge

Merrett, N. R., Roe, H. S. J. (1974). Patterns and selectivity in the feeding of certain mesopelagic fishes. Mar. Biol. 28: 115-126

Morse, D. H. (1971). The insectivorous bird as an adaptive strategy. Ann. Rev. Ecol. \& Syst. 2: 177-200

Muir, B. S., Nimi, A. J. (1972). Oxygen consumption of the euryhaline fish aholehole (Kuhlia scandvicensis) with reference to salinity, swimming and food consumption. J. Fish. Res. Bd Can. 29: 67-77

Odate, S. (1966). Studies on the fishes of the family Myctophidae in the north-western area of the Pacific coast of Japan. III. Determination of the age and growth of the suskihadaka lantern fish, Myctophum affine (Luetkın) (transl. from Jap. by Fish. Res. Bd Can. Transl. Ser. 850, 1967). Bull. Tohoku Reg. Fish. Res. Lab. 26: 35-43

Paloheimo, J. E., Dickie, L. M. (1966). Food and growth in fishes. II. Effects of food and temperature on the relation between metabolism and body weight. J. Fish. Res. Bd Can 23: 869-908

Raymont, J. E. G. (1963). Plankton and productivity in the oceans, Pergamon Press, Oxford

Roe, H. S. J. (1974). Observations on the diurnal vertical migrations of an oceanic animal community. Mar. Biol. 28: 99-113

Schoener, T. W. (1971). Theory of feeding strategies. Ann Rev. Ecol. \& Syst. 2: 369-404

Slobodkin, L. B. (1968). How to be a predator. Am. Zool. 8: 43-51

Smoker, W., Pearcy, W. G. (1970). Growth and reproduction of the lantern fish Stenobrachius leucopsarus. J. Fish. Res. Bd Can. 27: 1265-1275

Torres, J. J., Belman, B. W., Childress, J. J (1979). Oxygen consumption rates of midwater fishes as a function of depth occurrence. Deep Sea Res. 26: 185-197

Walters, J. F. (1976). Ecology of Hawaiian sergestid shrimps (Penaeidea: Sergestidae). Fish. Bull. U. S. 74: 799-836

Ware, D. M. (1975). Growth, metabolism and optimal swimming speed of a pelagic fish. J. Fish. Res. Bd Can. 32: 33-41

Warren, C. E., Davis, G. E. (1967). Laboratory studies on the feeding, bioenergetics and growth of fish. In: Gerking, S. D. (ed.) The biological basis of fresh-water fish production. Wiley, New York, pp. 175-214

Weatherley, A. H. (1972). Growth and ecology of fish populations, Academic Press, New York

This paper was submitted to the editor; it was accepted for printing on January 7,1981 